\title{
応答速度とノイズ低減のトレードオフを考慮したモータ速度制御系設計
}

\author{
横山 和人 ${ }^{* 1}$ ，家澤 雅宏 ${ }^{* 1}$
}

\section{Motor speed control system design considering a trade-off between response speed and noise reduction}

\author{
Kazuto YOKOYAMA*1 and Masahiro IEZAWA ${ }^{* 1}$ \\ ${ }^{* 1}$ Advanced Technology R\&D Center, Mitsubishi Electric Corporation \\ 8-1-1 Tsukaguchi-Honmachi, Amagasaki-shi, Hyogo 661-8661, Japan
}

Received 8 October 2015

\begin{abstract}
This paper proposes an automatic tuning method for a motor speed control system. Parameters of a PI controller and a low-pass filter (LPF) for motor speed signal are automatically derived satisfying required specifications of a time constant of step response and a tolerable steady-state error of ramp response. In addition, cut-off frequency of the LPF is set as low as possible, which solves the problem of a tradeoff between response speed and noise reduction. The method helps people to tune a speed controller without trial and error and reduces man-hour for developments. In the derivation of the proposed method, the coefficient diagram method (CDM) is utilized. In this paper, the stability index, the equivalent time constant, and the representation of characteristic polynomial defined in the CDM are theoretically linked to the specifications of the step and ramp responses. This enables the proposed method to directly incorporate the required performance for tuning the PI controller and the LPF. Simulations results show that the proposed method derive a desirable controller which satisfies the specifications as theoretically expected. Effectiveness is also verified in experiments in the presence of sensor noise of a resolver and the controller achieves desired performance without trial and error tuning of the parameters.
\end{abstract}

Key words : Motor, Speed control, PI control, Coefficient diagram method, Response speed, Noise reduction

\section{1. 緒言}

産業機器や自動車をはじめ世の中の至る所で使用されているモータにおいて，その速度制御系の設計方法は古 くから様々なものが提案されてきている. 代表的な構成としては，モータ速度信号をフィードバック情報とした PI (Proportional Integral) 制御がシンプルかつ実用的でしばしば用いられる。しかしながら，制御目的と制御対象 に依存して要求される応答性能は異なるとともに, センサノイズなどの問題もあることから，その都度 PI 制御系 やノイズ対策のフィルタの調整を試行錯誤的に行うことは開発工数の増大につながる. このような問題を解決す るために，PI 制御やD (Derivative) 動作を追加した PID 制御について，良好な応答性能を得るためのゲイン決定 方法がいくつも提案されている．例えば，限界感度法とステップ応答法 (Ziegler and Nichols, 1942) (杉江，藤田， 1999)，Chien-Hrones-Reswick 法 (Chien et al., 1952)，北森法 (1979)，および開ループ系のゲイン交差周波数と PI 制御系の折れ点周波数に着目する方法 (杉本他, 1990) が挙げられる. その他の決定法は Åström と Hägglund によ る著書などを参考にされたい (Åström and Hägglund, 1995). 一方, 産業界では速度制御系が満たすべき要求仕様が ステップ応答の時定数，ランプ応答の定常偏差，オーバーシュート量などで与えられることが多い. 前述のゲイ ン決定方法はそれらの要求仕様を直接的に満たすようには構成されておらず，最終的には試行錯誤的な微調整が 必要となる．特に応答速度の向上や定常偏差の低減のために制御系のゲインを増加させると，逆に速度信号のノ イズが増幅されるというトレードオフの中で調整することになる.

\footnotetext{
No.15-00552 [DOI:10.1299/transjsme.15-00552], J-STAGE Advance Publication date : 12 May, 2016

${ }^{* 1}$ 正員，三菱電機（株） 先端技術総合研究所（广661-8661 兵庫県尼崎市塚口本町 8-1-1）

E-mail of corresponding author: Yokoyama.Kazuto@ab.MitsubishiElectric.co.jp
} 


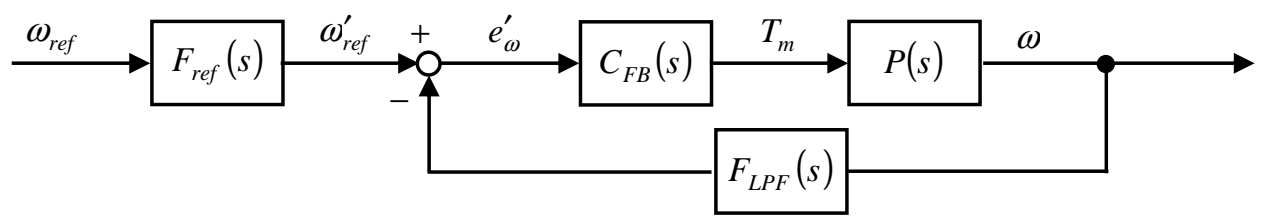

Fig. 1 Block diagram of the motor speed control system. The reference motor speed is shaped with a low-pass filter. It is designed as the 2nd-order one and to simplify the transfer function of the closed-loop system. The measured motor speed is also filtered with the 1st-order low-pass filter for noise reduction. The input torque for the motor is calculated with the PI controller using the error between the reference and actual motor speed.

本研究では 1 慣性系のモータ駆動システムにおいて, 要求仕様を直接的に考慮し, 試行錯誤的な調整をするこ となく PI ゲインを自動的に決定する設計法を提案する. 同時に，提案手法は要求仕様を満たす範囲内で速度信号 に対する LPF (Low-Pass Filter) のカットオフ周波数をできる限り小さくすることを特徵とする．これにより，応 答速度とノイズ低減のトレードオフを考慮した自動調整を実現し，速度制御系の開発工数を削減する．具体的な 方法として，本研究では係数図法を利用することで自動調整法を導出する．係数図法は閉ループ系の特性多項式 の係数に着目した代数的設計法の一種で，特性多項式と制御系を同時に設計することを特徵とする (真鍋, 1998, 2009). この手法では, 片対数グラフの縦軸に多項式の係数, 横軸に次数を表示した係数図と呼ばれるプロットの 形状を見ながら制御性能を調整する，安定性に関しては Routh-Hurwizの必要十分条件ではなく Lipatovの十分条 件を理論の基礎とすることで，判別式の複雑化を回避して実用性を向上させている．したがって，次数が大きい システムにも対応しやすい. 本研究では係数図法で用いられる安定度指標, 等価時定数およびそれらを用いた多 項式表現を利用し, 理論的にステップ応答の時定数とランプ応答の定常偏差の要求仕様と結び付けることで PI 制御系と LPFの自動調整法を導出する．有効性はシミュレーションおよび実機実験で示す.

\section{2. 制御系の構成}

速度制御系全体のブロック線図を図 1 に示寸。 $P(s)$ はモータ, $C_{F B}(s)$ は PI 制御系, $F_{L P F}(s)$ はモー夕速度信号 のノイズ除去用の LPF の伝達関数を表す． $F_{r e f}(s)$ は目標值の変化を骬らかに整形する LPFである． $\omega$ はモータ 速度， $\omega_{r e f}$ は目標モータ速度， $\omega_{r e f}^{\prime}$ は $F_{r e f}(s)$ 通過後のモータ速度である. $e_{\omega}^{\prime}$ はモータ速度偏差， $T_{m}$ はモータへ の制御入力トルクである. 各伝達関数の詳細を次に示す.

$$
\begin{aligned}
& P(s)=\frac{1}{J s} \\
& F_{L P F}(s)=\frac{1}{\tau_{L P F} s+1} \\
& C_{F B}(s)=K_{v p}+\frac{K_{v i}}{s} \\
& G_{C L}^{\prime}(s)=\frac{\left(K_{v p} s+K_{v i}\right)\left(\tau_{L P F} s+1\right)}{J \tau_{L P F} s^{3}+J s^{2}+K_{v p} s+K_{v i}}
\end{aligned}
$$

$J$ はモータ軸慣性モーメント， $\tau_{L P F}$ はモータ速度信号に対する LPF の時定数, および $K_{v p}$ と $K_{v i}$ はそれぞれ PI ゲインである. $G_{C L}^{\prime}(s)$ は $\omega_{r e f}^{\prime}$ から $\omega$ までの閉ループ系の伝達関数である， $F_{r e f}(s)$ を次式で定める.

$$
F_{r e f}(s)=\frac{K_{v i}}{\left(K_{v p} s+K_{v i}\right)\left(\tau_{L P F} s+1\right)}
$$


$F_{r e f}(s)$ は数式的に $G_{C L}^{\prime}(s)$ の零点を消去するように設計した. 零点が存在する場合, 非振動的な極をもつシステム でもオーバーシュートが発生することがあるが， $F_{r e f}(s)$ の挿入により応答を予想しやすくすることで, 所望の応 答性能を満たすゲイン設計の見通しをよくする. $F_{r e f}(s)$ の分子は $K_{v i}$ とすることで, 定常状態における $\omega_{r e f}$ から $\omega$ までの伝達関数のゲインを 1 とした。このとき図 1 のシステム全体の伝達関数は次式となる.

$$
G_{C L}(s)=\frac{K_{v i}}{J \tau_{L P F} s^{3}+J s^{2}+K_{v p} s+K_{v i}}
$$

$G_{C L}(s)$ は零点をもたないことから, 速度制御系の応答は PI 制御系のゲインと LPF の時定数からなる特性多項式 によって決定される.

\section{3. 制御系設計}

\section{$3 \cdot 1$ 係数図法にもとづく特性多項式の正規化}

制御対象が 2 次系であれば，よく知られた 2 次系の標準形の伝達関数と対比して固有振動数と減衰係数を考え ることで所望の応答を実現する制御系を設計できる．しかしながら，本研究ではモータ速度信号のノイズ低減を 目的とした LPF を挿入することから，システム全体は式 (6) に示寸通り 3 次系である. そこで，3 次系以上のシ ステムにも見通しよく対応可能な係数図法において用いられる定式化を利用する.

特性多項式は一般的に次式で表すことができる.

$$
Q(s)=a_{n} s^{n}+a_{n-1} s^{n-1}+\cdots+a_{1} s+a_{0}=\sum_{i=0}^{n} a_{i} s^{i}
$$

$n$ はシステムの次数, $a_{i}$ は特性多項式の定数係数である. 本研究では $n=3$ である. ここで, 係数図法において 次式で定義される安定度指標 $\gamma_{i}$, 等価時定数 $\tau_{e}$ を導入する.

$$
\begin{aligned}
& \gamma_{i}=\frac{a_{i}^{2}}{a_{i+1} a_{i-1}} \quad(i=1,2, \cdots, n-1) \\
& \tau_{e}=\frac{a_{1}}{a_{0}}
\end{aligned}
$$

これらを用いることで，特性多項式を下記の形に書き換えて考えることができる.

$$
Q(s)=a_{0}\left[\left\{\sum_{i=2}^{n}\left(\prod_{j=1}^{i-1} \frac{1}{\gamma_{i-j}^{j}}\right)\left(\tau_{e} s\right)^{i}\right\}+\tau_{e} s+1\right]
$$

多項式は $\tau_{e} s$ のべき乗と, 安定度指標からなる係数で表される. したがって, 応答波形は安定度指標で決まり, 等価時定数はその時間尺を決定するものとなる. 次節では $s^{\prime}=\tau_{e} s$ として $s^{\prime}$ 領域で応答を考えることで時間軸を 正規化し, 安定度指標のみによる応答波形の違いを検証する. 正規化された応答波形の中から望ましい形状のも のを選択し，その上で $\tau_{e}$ を適切に設定することで時間尺を変化させることにより所望の応答を得ることを目指す.

\section{$3 \cdot 2$ 正規化した 3 次系伝達関数の応答波形の検証}

本研究のシステムの式 (6) との対応関係を考え, 次の伝達関数の応答を検証する.

$$
G_{s}\left(s^{\prime}\right)=\frac{a_{0}}{Q\left(s^{\prime}\right)}=\frac{a_{0}}{a_{0}\left[\left\{\sum_{i=2}^{n}\left(\prod_{j=1}^{i-1} \frac{1}{\gamma_{i-j}^{j}}\right)\left(s^{\prime}\right)^{i}\right\}+s^{\prime}+1\right]}
$$




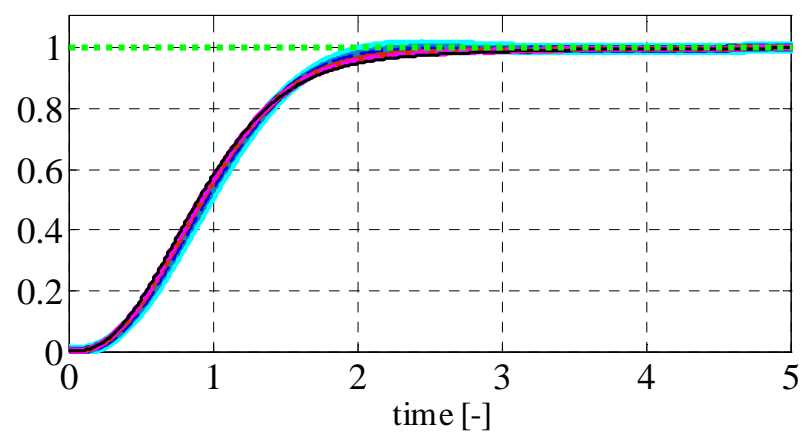

(a) Shape of normalized step responses.

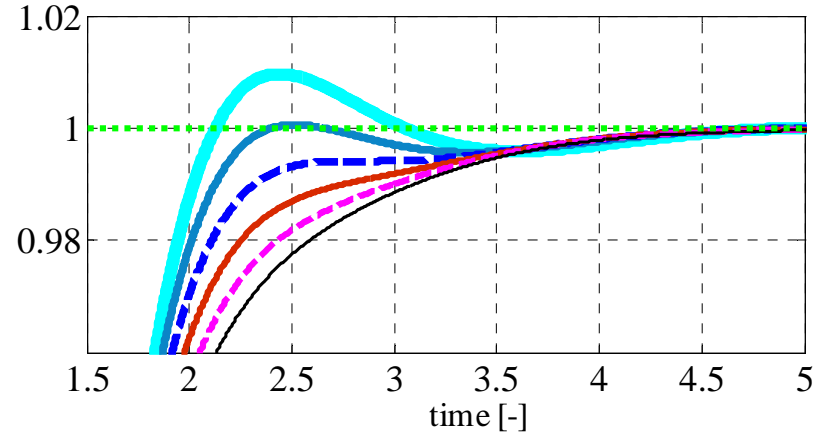

(b) Enlarged responses.

$$
\gamma_{1}=2.5-\gamma_{1}=2.6--\gamma_{1}=2.7-\gamma_{1}=2.8---\gamma_{1}=2.9-\gamma_{1}=3.0 \cdots \ldots \text { Reference }
$$

Fig. 2 Step responses of the 3rd-order system with normalized time ( $\gamma_{2}=2$ is fixed).The responses are verified varying $\gamma_{1}$ from 2.5 to 3. As $\gamma_{1}$ increases, the overshoot disappears and the responses become gentle. There is little difference in the speed of convergence among them.

Table 1 Relation between the normalized time constant of the 3rd-order system and the stability index. The normalized time constant can be converted into the actual time being multiplied by the equivalent time constant. The stability index should be selected considering a required specification for overshoot.

\begin{tabular}{ccccccc}
\hline Parameter & \multicolumn{6}{c}{ Value } \\
\hline \hline$\gamma_{1}$ & 2.5 & 2.6 & 2.7 & 2.8 & 2.9 & 3.0 \\
$\tau_{s}$ & 1.1359 & 1.1211 & 1.1077 & 1.0954 & 1.0842 & 1.0739 \\
\hline
\end{tabular}

Lipatov の安定十分条件によると, システムの安定性は全ての $\gamma_{i}$ を 1.5 以上に選ぶことで保証されることが示さ れている. また，全ての $\gamma_{i}$ を 4 以上に選ぶと特性多項式の全ての根が実数となり，過減衰の応答となることが証 明されている. 係数図法の理論では $\gamma_{i}$ は 1.5 から 4 の間で選ぶことが推奨されており, 特に応答性やロバスト性 の観点から次の值が標準值として提案されている (真鍋, 2009).

$$
\gamma_{n-1}=\cdots=\gamma_{2}=2, \quad \gamma_{1}=2.5
$$

標準值を用いる場合，オーバーシュートの有無は特に $\gamma_{1}$ の值に左右される. 理論的に 3 次系では $\gamma_{1} \geq 2.7$ とする とオーバーシュートがなくなることが報告されている (真鍋, 2009).

以上にもとづき， $\gamma_{n-1}=\cdots=\gamma_{2}=2$ に固定し， $\gamma_{1}$ の值を $2.5 \sim 3$ の間で変化させた場合のステップ応答波形を検 証した結果を図 2 に示寸， $\gamma_{1}$ の值が大きくなるに従ってオーバーシュートがなくなり，応答が緩やかになる方向 へ変化する. 収束の速さには大きな差は見られない. また，表 1 に各応答の時定数 $\tau_{s}$ を数值計算結果から読み取 った值を示す．この值にもとづき，所望のステップ忘答の時定数を満たすように $\tau_{e}$ を設定することで応答の時間 尺を変更する. オーバーシュート量に関する要求仕様がある場合は，それを考慮して $\gamma_{1}$ の值を決定することで対 応できる.

\section{$3 \cdot 3$ モ一夕速度制御系と係数図法による定式化の対応関係}

モータ速度制御系の $\omega_{r e f}$ から $\omega$ までの伝達関数 $G_{C L}(s)$ および特性多項式 $Q(s)$ は次式で表せる.

$$
G_{C L}(s)=\frac{K_{v i}}{Q(s)}
$$




$$
Q(s)=J \tau_{L P F} s^{3}+J s^{2}+K_{v p} s+K_{v i}
$$

$3 \cdot 1$ 節の定式化に当てはめて考えると次式が得られる.

$$
\begin{aligned}
& Q(s)=a_{0}\left\{\frac{1}{\gamma_{2} \gamma_{1}^{2}}\left(\tau_{e} s\right)^{3}+\frac{1}{\gamma_{1}}\left(\tau_{e} s\right)^{2}+\tau_{e} s+1\right\} \\
& a_{0}=K_{v i} \\
& \gamma_{1}=\frac{K_{v p}^{2}}{J K_{v i}} \\
& \gamma_{2}=\frac{J}{\tau_{L P F} K_{v p}} \\
& \tau_{e}=\frac{K_{v p}}{K_{v i}}=\tau_{L P F} \gamma_{1} \gamma_{2}
\end{aligned}
$$

式 (19) より, 等価時定数 $\tau_{e}$ はモータ速度信号に対する $\mathrm{LPF}$ の時定数 $\tau_{L P F}$ と安定度指標 $\gamma_{1}, \quad \gamma_{2}$ により決まる. し かし， $\gamma_{1}$ と $\gamma_{2}$ は係数図法により推奨される值を設定寸ることが安定性や応答波形の観点から適切であるため, $\tau_{e}$ は実質的に $\tau_{L P F}$ に依存すると考えてよい， $\tau_{e}$ は図 2 の波形の時間尺を決める（つまり速応性を決める）パラメー タであることを踏まえると, 速度制御系の応答速度は $\tau_{L P F}$ の設計により規定される.

\section{$3 \cdot 4$ ステップ応答に関する要求仕様を満たすための条件の定式化}

時間を正規化した 3 次系の応答の時定数 $\tau_{s}$ に対して, 実際の応答の時定数は $\tau_{e} \tau$ となる. 要求仕様の時定数を $\tau_{d}$ とすると, 実際の応答の時定数を $\tau_{d}$ 以下とするための条件式は次式となる.

$$
\begin{aligned}
& \tau_{d} \geq \tau_{e} \tau_{s}=\tau_{L P F} \gamma_{1} \gamma_{2} \tau_{s} \\
& \Rightarrow \tau_{L P F} \leq \frac{\tau_{d}}{\tau_{s} \gamma_{1} \gamma_{2}}
\end{aligned}
$$

$\gamma_{1}$ の值は図 2 の時間を正規化した 3 次系の応答波形から所望のものを選ぶことで決まり， $\tau_{s}$ は表 1 から $\gamma_{1}$ の值に 応じて一意に決まる. したがって, 所望の時定数 $\tau_{d}$ に応じて式 (21) を満たすように LPF の時定数 $\tau_{L P F}$ を与える ことで, 時定数が $\tau_{d}$ 以下となる実際の応答波形が得られる.式 (21) の等号が成立するように $\tau_{L P F}$ を与えた場合, 実際の応答の時定数は $\tau_{d}$ と等しくなる. PI 制御系のゲイン $K_{v p}, K_{v i}$ は式 (17), (18) より $\gamma_{1}, \gamma_{2}$ および $\tau_{L P F}$ を 与えた時点で自動的に決定される.

\section{$3 \cdot 5$ ランプ応答に関する要求仕様を満たすための条件の定式化}

ランプ応答に関する要求仕様として, 目標加速度 $a_{r e f}$ での追従時の定常偏差の許容值を $e_{\text {ramp }}$ 以下にすることを 考える. 定常偏差 $e_{\omega S S v}$ は, 閉ループ系の伝達関数式 (6) から次式となる.

$$
e_{\omega S S v}=a_{r e f} \frac{K_{v p}}{K_{v i}}=a_{r e f} \tau_{e}=a_{r e f} \tau_{L P F} \gamma_{1} \gamma_{2}
$$

$\gamma_{1}, \gamma_{2}$ は正規化した 3 次系の応答波形で所望のものを選択することで決定されることから，ランプ応答の定常偏 差を小さくするためには， $\tau_{L P F}$ を小さく設定すればよい.

ランプ応答の定常偏差の許容值 $e_{\text {ramp }}$ と式 (22) より次の条件式が得られる. 


$$
\tau_{L P F} \leq \frac{e_{\text {ramp }}}{a_{r e f} \gamma_{1} \gamma_{2}}
$$

この式を満たすように $\tau_{L P F}$ を決定することでランプ応答の定常偏差を許容值以下にできる.

\section{$3 \cdot 6$ 制御系設計手順のまとめ}

以下の手順を踏むことで，ステップ応答の時定数，ランプ応答の定常偏差，およびオーバーシュートに関する 要求仕様を満たすモータ速度制御系を手続き的に設計することができる.

Step 1. 速度制御系の構成を図 1 のように定める.

Step 2. 時間を正規化した式 (11) の 3 次系の伝達関数 $G_{s}\left(s^{\prime}\right)$ のステップ応答から, 所望の波形となる $\gamma_{1}$ と $\gamma_{2}$ を 選択する. オーバーシュートに関する要求には $\gamma_{1}$ を適切に設定することで対応できる.

Step 3. $G_{s}\left(s^{\prime}\right)$ のステップ応答から時定数 $\tau_{s}$ を読み取る.

Step 4. 要求仕様などにもとづき, 実際の速度制御で達成したいステップ応答の時定数 $\tau_{d}$ を定める.

Step 5. 次式を満たす範囲内で, LPF の時定数 $\tau_{L P F}$ を決定する.

$$
\tau_{L P F} \leq \min \left(\frac{\tau_{d}}{\tau_{s} \gamma_{1} \gamma_{2}}, \frac{e_{\text {ramp }}}{a_{r e f} \gamma_{1} \gamma_{2}}\right)
$$

等号が成立する $\tau_{L P F}$ を選択することは要求仕様を満たす応答波形と速応性を実現可能な範囲内で，でき る限り低い LPF のカットオフ周波数を設定することを意味する.これは速度信号のノイズ除去の観点か ら望ましい設定といえる.

Step 6. PI 制御系のゲインを計算する．計算式は式 (17), (18) を変形することで得られる.

$$
\begin{aligned}
& K_{v p}=\frac{J}{\tau_{L P F} \gamma_{2}} \\
& K_{v i}=\frac{K_{v p}^{2}}{J \gamma_{1}}=\frac{J}{\tau_{L P F}^{2} \gamma_{1} \gamma_{2}^{2}}
\end{aligned}
$$

\section{4. 数值解析}

\section{$4 \cdot 1$ 提案設計法によるPI 制御系と LPF のパラメータの決定}

制御系設計法の有效性を数值解析により検証する．前述の手順に沿って具体的なパラメータを決定する．Jは 実験機にもとづき $0.020 \mathrm{kgm}^{2}$ とする.

Step 1. 制御系の構成は図 1 に示すものとする.

Step 2. $\gamma_{1}$ と $\gamma_{2}$ を決定する. $\gamma_{2}$ は係数図法の理論において標準值として推奨されている $\gamma_{2}=2$ を用いる. 図 2 の時間を正規化した 3 次系の応答から，オーバーシュートが非常に小さく，応答の立ち上がりが速い $\gamma_{1}=2.6$ を採用する.

Step 3. 応答波形から時定数 $\tau_{s}$ を読み取る. $\gamma_{1}=2.6$ としたときの值は表 1 に示しており $\tau_{s}=1.1211$ である.

Step 4. 要求仕様にもとづき実際の応答の所望の時定数 $\tau_{d}$ を決定するが，PI ゲインと LPF のカットオフ周波数 を比較するため, 本研究では $0.050 \mathrm{~s}$ と $0.040 \mathrm{~s}$ の 2 種類を用意する. またランプ応答の目標加速度は $a_{\text {ref }}=1000 \mathrm{rpm} / \mathrm{s}$ とし, 定常偏差の許容值を $e_{\text {ramp }}=55 \mathrm{rpm}$ とする.

Step 5. LPF の時定数 $\tau_{L P F}$ を条件式 (24) にもとづき決定する. ここでは等号が成立するように $\tau_{L P F}$ を設定する. $\tau_{d}=0.050$ と $\tau_{d}=0.040$ の 2 つ場合それぞれに対して， $\tau_{L P F}=0.0086 ， \tau_{L P F}=0.0069$ が得られた。 お，どちらの場合も式 (24)の min 内は第 1 要素の方が小さかったため, 実際の速度制御の応答時定数は ちょうど $\tau_{d}$ になることが予想される. 
Table 2 Parameters of the PI controller and the LPF. They are automatically tuned with the proposed method using the given required time constant $\tau_{d}$.

\begin{tabular}{ccc}
\hline Parameter & \multicolumn{2}{c}{ Value } \\
\hline \hline$\tau_{d}[\mathrm{~s}]$ & 0.050 & 0.040 \\
$\tau_{L P F}[\mathrm{~s}]$ & 0.0086 & 0.0069 \\
$f_{L P F}[\mathrm{~Hz}]$ & 18.6 & 23.2 \\
$K_{v p}$ & 1.17 & 1.46 \\
$K_{v i}$ & 26.2 & 40.9 \\
\hline
\end{tabular}

Table 3 Results of the time constant and the steady-state error in the simulations. The step and ramp responses satisfy the required time constant and steady-state error as theoretically expected. They are realized without trial and error tuning of the controller parameters.

\begin{tabular}{ccc}
\hline$\tau_{d}[\mathrm{~ms}]$ & 50 & 40 \\
\hline \hline $\begin{array}{c}\text { Time Constant } \\
\text { (Step Response) }\end{array}$ & $50.0 \mathrm{~ms}$ & $40.0 \mathrm{~ms}$ \\
\hline $\begin{array}{c}\text { Steady-State Error } \\
\text { (Ramp Response) }\end{array}$ & $44.7 \mathrm{rpm}$ & $35.9 \mathrm{rpm}$ \\
\hline
\end{tabular}

Step 6. PI 制御系のゲインを式 (25)，(26) から計算する.

シミュレーションと実機実験で用いる制御系のパラメータを表 2 に示す. $\tau_{d}=0.040$ の場合の方が，速応性向 上のためPI ゲインが大きい計算結果となった．同時に LPF のカットオフ周波数 $f_{L P F}$ も大きくなっており, 提案 手法により速応性とノイズ低減のトレードオフが自動調整されていることがわかる。

\section{$4 \cdot 2$ ステップ応答とランプ応答の検証}

図 3 (a) にステップ応答の時刻暦を示す. 試験条件として回転数を $400 \mathrm{rpm} \rightarrow 1000 \mathrm{rpm}$ ヘテテップ状に変化さ せた. 表 3 に数值解析結果から読み取った時定数の值を示す.いずれの結果も理論通りに定常偏差なく収束して いる. 実応答の時定数は制御系の設計段階で設定した $\tau_{d}$ の值と一致している. なお，オーバーシュートは図 2 に おいて $\gamma_{1}=2.6$ の波形を選択したため理論的に必ずわずかに発生する.

図 3 (b) にランプ応答の時刻暦を示す. 試験条件として回転数を $1100 \mathrm{rpm} \rightarrow 1600 \mathrm{rpm}$ ヘランプ状に変化させ た. 表 3 に数值解析結果から読み取った定常偏差の值を示す. いずれの結果も要求仕様である $55 \mathrm{rpm}$ 以下を満 たしている，定常偏差の值も，式 (22) で与えられる理論值と一致することが計算により確認できる.

\section{5. 実機検証}

提案する設計法によりパラメータを決定した速度制御系の実機検証を行う。検証に用いた実験装置の構成を図

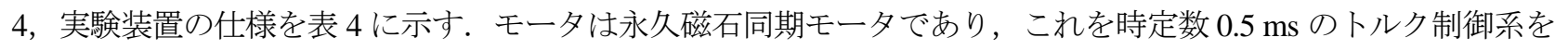
有するインバータで駆動した。インバータのコントローラには Myway プラス社の PE-Expert3 (DSP : TMS6713, CLK : $225 \mathrm{MHz}$ ）を用いた. コントローラへの速度制御プログラムの書き込み，およびコントローラの内部変数 の取得は Myway プラス社の専用ソフトウェアを用いた．モータ軸の位置検出器にはレゾルバを使用した。レゾ ルバの検出信号は R/D コンバータでモータ 1 回転 14 bit の角度信号に変換し，これを $0.1 \mathrm{~ms}$ のサンプリング周期 で時間微分することで速度信号を取得した．速度制御の PI 制御系と LPF のパラメータは，シミュレーションと 同様にステップ応答の時定数を $\tau_{d}=50 \mathrm{~ms}$ として設計したものを用いる. 実験では試行錯誤的なパラメータ調整 は一切行わなかった．レゾルバはその検出原理に起因してモータ速度と同期した脈動が信号に重畳する。これは 

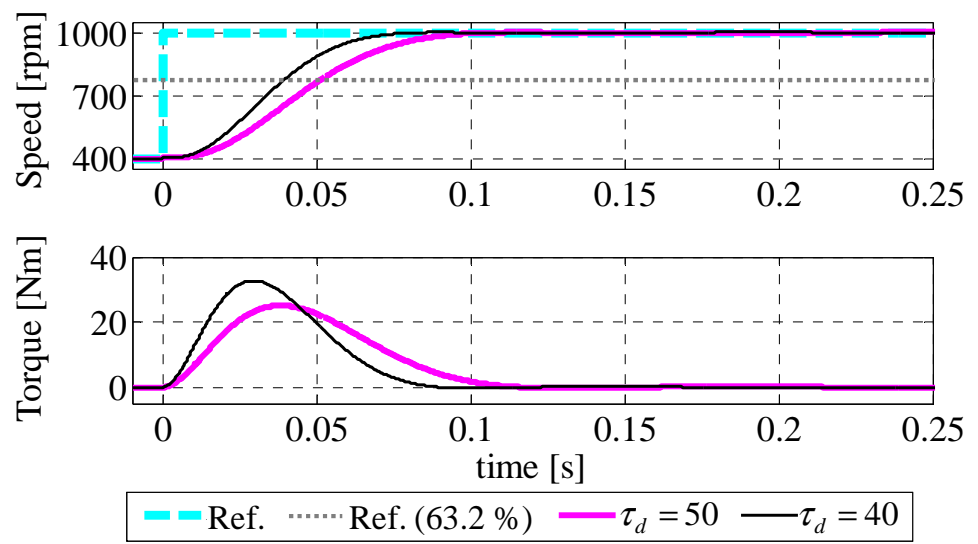

(a) Step responses.
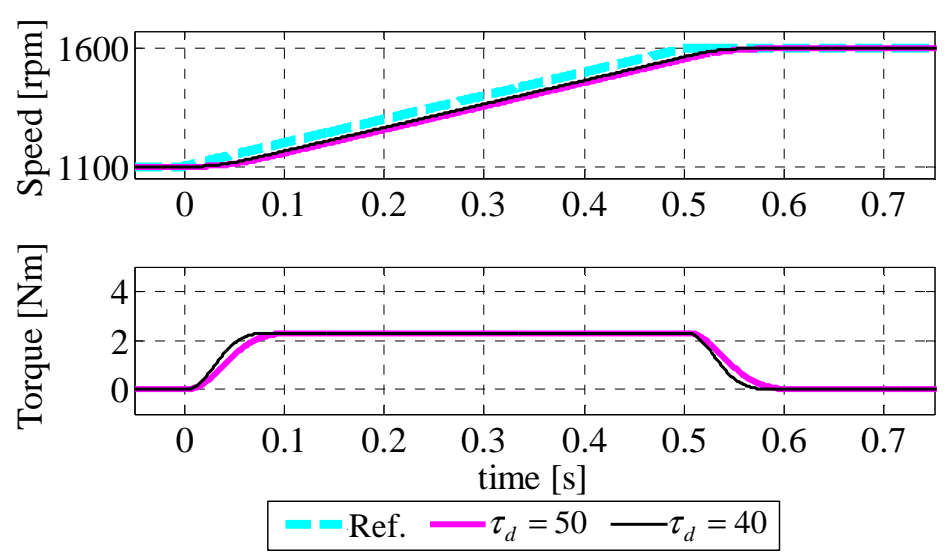

(b) Ramp responses.

Fig. 3 Simulation results with different $\tau_{d}$. The step and ramp responses satisfy the required time constant and steady-state error as theoretically expected. They are realized without trial and error tuning of the controller parameters.

速度制御系の性能に悪影響を及ぼすが，提案手法により LPF のカットオフ周波数をできる限り低く設計すること で影響が低減されることが期待できる.

ステップ応答の実験結果のプロットを図 5 (a), 時定数の結果を表 5 に示す. トルク波形がわずかに波打ってお り, これがレゾルバ信号の脈動の影響である. 速度の増加とともに脈動の周波数も増加している. しかしながら, モータ速度はオーバーシュートなく目標へ収束するとともに, 時定数は $50 \mathrm{~ms}$ ちょうどの結果が得られ要求仕様 を満たしている. ランプ応答の実験結果のプロットを図 $5(\mathrm{~b})$, 定常偏差の最大值の結果を表 5 に示寸. 定常偏差 に関する要求仕様は $55 \mathrm{rpm}$ 以下であり, 実験結果はこれを満たす結果となった. 定常偏差の理論值は表 3 より $44.7 \mathrm{rpm}$ であり, 実験ではレゾルバ脈動の影響などで性能がやや劣化している．ただし，表 5 に示した定常偏差 は最悪值であり, 平均的には理論值から大きく外れてはいない. 以上より, 提案設計法にもとづき決定した PI 制御系と LPF のパラメータにより, 試行錯誤することなくステップ・ランプ応答の要求仕様を満たす制御系が得 られることを確認した。

\section{6. 結 言}

1 慣性系のモータ速度制御系において, ステップ・ランプ応答の要求仕様を直接的に考慮しながら, PI ゲイン およびモータ速度信号のノイズ低減用の LPF のカットオフ周波数を自動調整する設計法を提案した. カットオフ 周波数は要求仕様を満た寸範囲内でできる限り低く設定するため, センサノイズによる性能劣化も極力抑えるこ とができる.これにより開発工数を削減しつつ所望の速度制御系を得ることができる. 提案設計法は係数図法で 


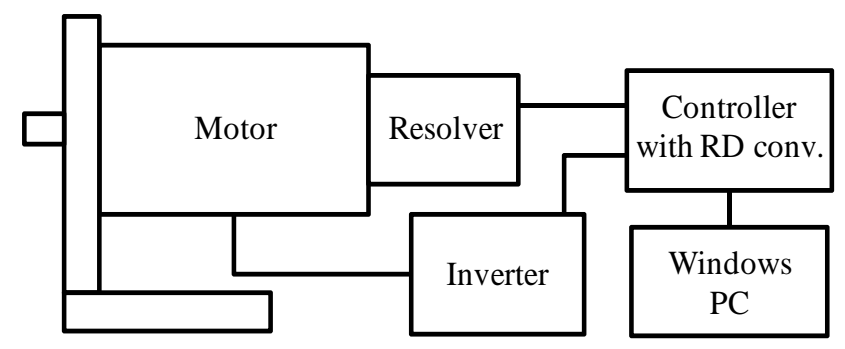

Fig.4 Configuration of the experimental system. A permanent magnet synchronous motor is used. It is driven with an inverter which has a torque controller with time constant $0.5 \mathrm{~ms}$. The rotor position is measured with a resolver. The motor speed is calculated differentiating the position signal with sampling time $0.1 \mathrm{~ms}$.

Table 4 Specifications of the experimental system. The time constant of the torque control and sampling period of the speed control are designed fast enough to satisfy the required specification.

\begin{tabular}{cc}
\hline Item & Value \\
\hline \hline Rated power & $20 \mathrm{~kW}$ \\
\hline Rated torque & $25 \mathrm{Nm}$ \\
\hline Rated speed & $9000 \mathrm{rpm}$ \\
\hline Rotor inertia & $0.020 \mathrm{kgm}^{2}$ \\
\hline Resolution of position sensor & $0.000383 \mathrm{rad}$ \\
\hline Time constant of torque control & $0.5 \mathrm{~ms}$ \\
\hline $\begin{array}{c}\text { Sampling period of } \\
\text { motor speed control }\end{array}$ & $0.1 \mathrm{~ms}$ \\
\hline
\end{tabular}

用いられる安定度指標, 等価時定数およびそれらを用いた多項式表現を, 産業界でしばしば用いられるステップ・ ランプ応答の要求仕様と理論的に結び付けたことが特徴である。シミュレーションにより理論通りの結果を確認 するとともに，試行錯誤的な調整を排した実機実験においても所望の制御性能が得られることを示した．なお， 本研究では基礎検討としてモータは無負荷条件で議論しており, 変動負荷がある場合は, 提案手法をそのまま適 用しても時定数や定常偏差の要求仕様を満たすことは保証されない，負荷慣性モーメントが変動する場合は，才 ンラインでそれを推定し，パラメータ $J$ に反映させた上で提案アルゴリズムを用いて制御系パラメータを更新す ることが対処方法の 1 つである. 外力モーメントなどが働く場合は，それを推定して相殺するフィードバック制 御が必要になると考えられる．また，本研究は 3 次系を対象として制御系設計を行ったが，設計の基礎となる応 答波形は $n$ 次系の式 (10) で定義される. さらに応答波形の時間尺（つまり速応性）は等価時定数 $\tau_{e}$ にりり独立 に調整可能である. したがって, 提案設計法はより高次のシステムへ拡張できる可能性が高く, 今後検討してい きたい. 

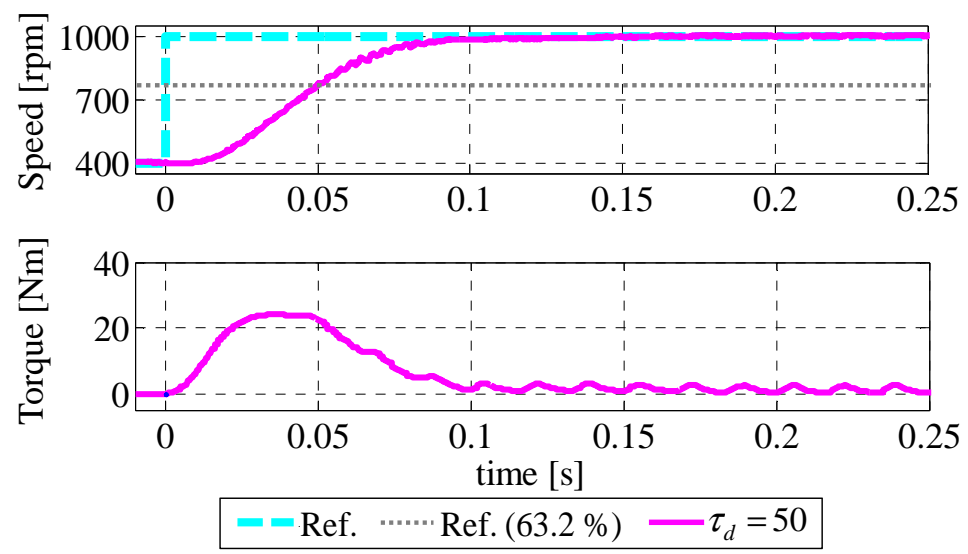

(a) Step responses.
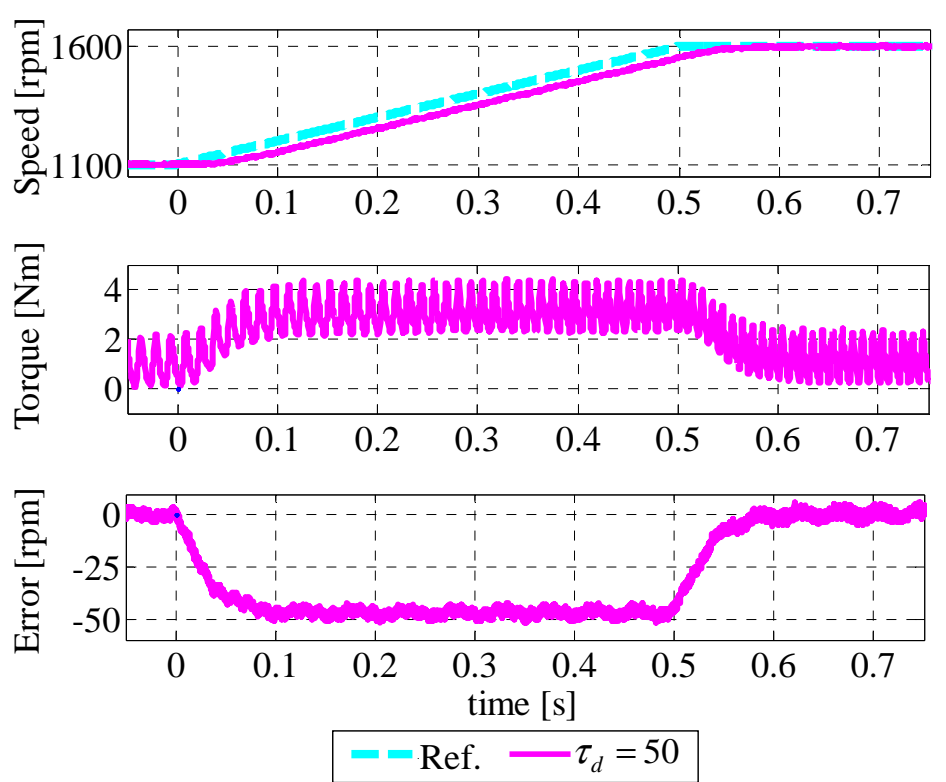

(b) Ramp responses.

Fig.5 Experimental results with $\tau_{d}=0.050 \mathrm{~s}$. The parameters of the control system are determined using the proposed tuning algorithm. The motor speed converges to the reference value without overshoot. The required specifications for the time constant and steady-state error are satisfied without trial and error even in the presence of the ripple from the resolver signal. The noise is suppressed with the low-pass filter whose cutoff frequency is optimized with the proposed method.

Table 5 Results of the time constant and the steady-state error in the experiments. The required specifications are satisfied in the actual setup. The time constant of the step response achieves the desired performance as theoretically expected. The steady-state error of the ramp response is slightly deteriorated because of the ripple generated from the resolver. However, the low-pass filter tuned with the proposed method effectively reduces the noise.

\begin{tabular}{cc}
\hline $\begin{array}{c}\text { Time Constant }[\mathrm{ms}] \\
\text { (Step Response) }\end{array}$ & $\begin{array}{c}\text { Steady-State Error [rpm] } \\
\text { (Ramp Response) }\end{array}$ \\
\hline 50.0 & -52.02 (Worst Value) \\
\hline
\end{tabular}




\section{文献}

Åström, K. and Hägglund, T., PID Controllers Theory, Design, and Tuning, 2nd Edition (1995), Instrument Society of America.

Chien, K. L., Hrones, J. A. and Reswick, J. B., On the automatic control of generalized passive systems, Transactions of the ASME, Vol. 74 (1952), pp. 175-185.

北森俊行, 制御対象の部分的知識にもとづく制御系の設計法, 計測自動制御学会論文集, Vol. 15, No. 4 (1979), pp. 549-555.

真鍋舜治, 係数図法による 2 慣性共振系制御器の設計, 電気学会論文誌 D, Vol. 118, No. 1 (1998), pp. 58-66.

真鍋舜治, 係数図法 制御系設計の理論と応用 (online), available from

< http://www.cityfujisawa.ne.jp/ manabes/index.htm> (2009), (参照日 2015 年 9 月 14 日).

杉江俊治, 藤田政之, フィードバック制御入門 (1999), コロナ社.

杉本英彦, 小山正人, 玉井伸三, AC サーボシステムの理論と設計の実際 (1990), 総合電子出版社.

Ziegler, J. G. and Nichols, N. B., Optimum settings for automatic controllers, Transactions of the ASME, Vol. 64 (1942), pp. 759-768.

\section{References}

Åström, K. and Hägglund, T., PID Controllers Theory, Design, and Tuning, 2nd Edition (1995), Instrument Society of America.

Chien, K. L., Hrones, J. A. and Reswick, J. B., On the automatic control of generalized passive systems, Transactions of the ASME, Vol. 74 (1952), pp. 175-185.

Kitamori, T., A method of control system design based upon partial knowledge about controlled processes, Transactions of the Society of Instrument and Control Engineers, Vol. 15, No. 4 (1979), pp. 549-555 (in Japanese).

Manabe, S., Controller design of two-mass resonant system by coefficient diagram method, IEEJ Transactions on Sensors and Micromachines, Vol. 118, No. 1 (1998), pp. 58-66 (in Japanese).

Manabe, S., Coefficient diagram method for control system design (online), available from < http://www.cityfujisawa.ne.jp/ manabes/index.htm > (2009), (accessed on 14 September, 2015).

Sugie, T. and Fujita, M., Introduction to Feedback Control (1999), Corona Publishing CO., LTD (in Japanese).

Sugimoto, H., Koyama, M. and Tamai, S., Practice of Theory and Design on AC Servo System(1990), Sougosyuppansha (in Japanese).

Ziegler, J. G. and Nichols, N. B., Optimum settings for automatic controllers, Transactions of the ASME, Vol. 64(1942), pp. 759-768. 